\title{
EFFECT OF SALVAGE LOGGING AND CHECK-DAMS ON SIMULATED HYDROLOGICAL CONNECTIVITY IN A BURNED AREA
}

\author{
SHORT TITLE: MODELLING HYDROLOGICAL CONNECTIVITY IN BURNED AREAS
}

Juan F. Martínez-Murillo ${ }^{1}$, Manuel López-Vicente ${ }^{2 *}$ [ORCID IDs: 0000-0002-8963-0505, 0000-0002-6379-8844]

${ }^{1}$ Departamento de Geografía, Universidad de Málaga, Campus Internacional Andalucía Tech. Campus de Teatinos, 29071 Málaga, Spain.

${ }^{2}$ Department of Soil and Water, Experimental Station of Aula Dei, EEAD-CSIC. Av. Montañana 1005, 50059 Zaragoza, Spain.

*Correspondence to: Manuel López-Vicente. Tel. +34 976-716-124; Fax +34 976-716-145; E-mail address: $\underline{\text { mvicente@eead.csic.es }}$

Received 28 December 2016; Revised 19 February 2017; Accepted 19 February 2017 Published online in Wiley Online Library (wileyonlinelibrary.com)

DOI: $10.1002 / \mathrm{ldr} .2735$

\section{Land Degradation \& Development}

1

ABSTRACT

This study assessed the effect of a wildfire and different post-fire practices (salvage logging, skid trails and check-dams) and vegetation recovery (eight scenarios) on the hydrological connectivity (HC) in eleven sub-catchments (330 ha) affected by a wildfire (213 ha) in 2012 in Spain. According to the Landsat 8 OLI/TIRS images, moderate, high and extreme burn severity affected $42.1 \%$ of the area. HC was calculated with an updated version of the Borselli's index. Within the burned area (BA), HC increased in all sub-catchments (SubC) after the wildfire (PostF-1), the salvage logging and the new skid trails (PostF-2), and the development of new gullies (PostF-3). Check-dams reduced connectivity but did not prevent the general trend. Afterwards, the incipient (PostF-4 and -5) and future vegetation recovery made slightly decrease HC. In the three forestry SubC with check-dams and large BA (67\% of the study area), connectivity markedly increased (11.4, 18.2 and $22.9 \%)$ during the three first post-fire scenarios. In the $3 \mathrm{SubC}$ with urban areas and small BA (5\%), HC decreased a little because the linear elements connected the hillslopes between them. In the 3 SubC with 
urban areas and large BA (12\%), HC increased less than in the forestry SubC (3.0, 8.2 and $9.1 \%)$. In the 2 forestry SubC without check-dams and small BA (16\%), the increment of connectivity was low $(2.5,4.6$ and $6.3 \%)$. Monitoring of check-dam siltation and of the actual vegetation regrowth is necessary to minimize the off-site consequences of high $\mathrm{HC}$.

KEY WORDS: hydrological connectivity; wildfire; salvage logging; rill erosion; post-fire scenarios

\section{INTRODUCTION}

Dependent on fire severity, wildfires modifies the physical, chemical and hydrological soil properties (Shakesby \& Doerr, 2006; Shakesby, 2011; Robichaud et al., 2013; Malvar et al., 2016a). Soil surface conditions also change, and runoff and erosion processes enhance, especially, when ash cover is completely removed (Bodí et al., 2012; Martínez-Murillo et al., 2016a). The post-fire spatial distribution of soils and vegetation patterns plays an important role from the hydro-geomorphic point of view. If no obstacle exists to overland flow and eroded sediment progression, the fluxes from hillslopes reach the catchment channel easily, producing higher runoff compared to unburned areas (Ferreira et al., 2008). This results in an increment in the hydrological (runoff and sediment) connectivity (HC) through different spatial scales, from patches and hillslopes to the entire catchment (Estrany et al., 2016; Prats et al., 2016).

The interaction between topography and processes occurring within catchments is key to understanding dynamics of HC (Bracken \& Croke, 2007; Wainwright et al, 2011). Turnbull et al. (2008) defined structural connectivity as the spatial patterns in the landscape (e.g., the spatial distribution of landscape units which influence water transfer patterns and flow paths) and functional connectivity as how these spatial patterns interact with catchment processes to produce runoff, connected flow and hence water transfer in catchments. However, the spatial and temporal variability of other elements within the landscape, such as land uses and human infrastructures, can modify that dynamic of runoff generation and sediment delivery (LópezVicente et al., 2011). This is especially remarkable when wildfires occur and modify vegetation cover.

In burned Mediterranean ecosystems, it is not so frequent the rilling and gullying processes compared to others as reported for the USA (Robichaud, 2000; Cannon \& Gartner, 2005). 
The great volume of stones in the soil surface and profile is given as the main reason for that (Shakesby, 2011). However, this rarity in the formation of rills and gullies can be modified due to the post-fire management of the burned area, especially, when burned trees are removed. Salvage logging has been reported as one of the major problems which can greatly enhanced post-fire erosion and soil losses as well as making possible the development of rills and gullies (Malvar et al., 2016b). The opening of new skid trails, regardless the equipment type and the amount of traffic, increases the risk of sedimentation (Wagenbrenner et al., 2016). Therefore, areas disturbed by ground-based salvage logging after high severity fires need additional mitigation practices (Wagenbrenner et al., 2015).

These eco-geomorphological processes become dramatically relevant when wildfires affect what has been called 'Wildland-Urban Interface' (WUI), defined as the area where structures and other human development meet or intermingle with undeveloped wildland (Lein \& Stump, 2009). The study of HC within the burned area in WUI becomes especially complex due to the itself-complexity of $\mathrm{HC}$ within urban areas (Ferreira et al., 2016). Additionally, the increase of $\mathrm{HC}$ in this type of landscape has seriouos off-site effects such as the increment of flooding hazards.

Most published scientific studies relating $\mathrm{HC}$ and wildfire corresponded to experimental approaches in field conditions by means of either rainfall simulations, plots, gauging stations, tracers or radionuclides (Martínez-Murillo et al., 2016b). However, it is found a scientific gap in the literature focussed on modelling of $\mathrm{HC}$ in burned areas. Most available $\mathrm{HC}$ indices are based on Geographic Information Systems (GIS) and stream-power approaches, such as the "volume to breakthrough" of Bracken \& Croke (2007), and the Connectivity of Runoff Model, 2D version, of Reaney et al. (2014). A few years ago, Borselli et al. (2008) developed the index of runoff and sediment connectivity (IC) testing successfully this approach in a large catchment in Central Italy against field observations. This qualitative index accounts the combined effect of the upslope topographic and land-use characteristics and those values of the same parameters throughout the flow path line that a soil particle has to travel to arrive at the nearest defined stream or sink. The ability of this index has been proved in different fields and catchments, such as in Austria (Heckmann \& Schwanghart, 2013), France (Gay et al., 2016) and Japan (Chartin et al., 2013). In Spain, the studies of López-Vicente et al. (2013, 2016) and Foerster et al. (2014) proved its capacity to map runoff and sediment connectivity. In this study, we simulate the evolution of HC in a WUI area affected by a wildfire and subsequent salvage post-fire management. Namely, the objectives are to: i) modelling the HC in pre-fire, burned, different post-fire management conditions and two potential future 
scenarios by means of an updated version of the Borselli's index; ii) characterize and validate the simulated HC under field conditions; and iii) analyse the evolution of $\mathrm{HC}$ in the different types of sub-catchments (based on the human-induced changes) and geomorphic features.

\section{STUDY AREA}

The study area is located in South of Spain (Province of Malaga) and corresponds to eleven headwater sub-catchments (total area of $330 \mathrm{ha}$ ) that cover the entire burned area (Figure 1). The fire started in 2014, 27 June and lasted two days, affecting 223 ha in total and 213 ha within the study area (65\% of the surface). The landscape is mainly mountainous, ranging from 630 to 1,102 m.a.s.l., with very steep slopes (>30\%) and marbles as parent material. The climate is Mediterranean, with mean annual rainfall and temperature of $600 \mathrm{~mm}$ and $17^{\circ} \mathrm{C}$ during the latest 27 years (data source: Agencia Andaluza del Agua). The previous land use to the wildfire corresponded to shrublands (Rosmarinus officinalis L., Stipa tenacissima L., Cistus clusii L., Lavandula stoechas L., Daphne gnidum L.) and forests of Pinus pinaster L. Few olive and fruit groves appear at the bottom of the slopes, and abandoned olive groves are intersected between the disperse settlements in the lower part of the slopes. The dense urban area corresponds to Cómpeta village. Soils are normally shallow (less than $15 \mathrm{~cm}$ depth), with high content of rocks as well as sandy texture; these were mainly skeletic and calcaric Leptosols with inclusions of Regosols.

The burned area partly covers the WUI in its southern limit (Figure 1). Salvage logging started seven days after ending the fire and lasted four days. This consisted in cutting all trees, equally completely, partially and unburned trees, and taking them out by dragging upslope. Thus, new skid trails were built. Many erosive morphologies, as rills and gullies, were enhanced due to this post-fire management. The removal of burned trees was carried out by means of their dragging down-to-up the hillslopes using cables. This technique left some marks and incisions, which were taken advantage by the overland flow.

\section{METHODS AND SCENARIOS}

\section{Wildfire images acquisition and processing}

Two-Landsat 8 OLI/TIRS images were downloaded from the United States Geological Survey (USGS) Global Visualization Viewer (http://glovis.usgs.gov/) for the pre-fire (path: 201, raw: 34; date: 18/Jun/2014) and post-fire scenario (path: 201, raw: 34; date: 
04/Jul/2014). Both images presented a spatial resolution of $30 \times 30 \mathrm{~m}$ and $15 \times 15 \mathrm{~m}$ for the multispectral and panchromatic bands, respectively. The atmospheric correction was performed using the dark object method (band-fixed transmissivity values; Chavez, 1996). Afterwards, the multispectral and panchromatic bands were merged by means of the local regression technique of pansharpening in TerrSet 1.0 (C) (Clark Labs, Clark University). This process let improve the spatial resolution of multispectral bands to $15 \times 15 \mathrm{~m}$. Secondly, images were geometrically rectified using a second-order polynomial model to minimize the loss of spatial accuracy of the data and included in ENVI 4.8 ( ). Thus, image to map registration was performed using 154 commonly identified Ground Control Points (GCPs) between the different datasets. The nearest neighbour interpolation was employed to resample the image. This method better preserves the digital number (DN)/reflectance values in the original images. A mean Root Mean Square (RME) error registration below the OLI pixel was obtained in all cases that was considered satisfactory. Another image with major spatial resolution (1 x $1 \mathrm{~m}$ ) from Google Earth (Digital Globe (C) was downloaded (Date: $27 / \mathrm{Jul} / 2015$ ) in order to photo-interpret the post-fire rill and gully network.

\section{Burn severity assessment}

Burn severity was mapped by means of the Normalized Burn Ratio (NBR). According to Key \& Benson (2005), this index highlights burned areas indicating the severity of burn. NBR calculates the differing responses of Landsat bands 4 (Near Infrared, NIR, 0.64-0.67 mm) and 6 (Short-wave Infrared, SWIR, 1.57-1.65 mm), which are sensitive to changes in soil and vegetation moisture (Garcia \& Caselles, 1991):

$$
N B R=\frac{N I R-S W I R}{N I R+S W I R}
$$

The NBR was calculated for both pre and post-fire scenarios what made possible to difference both pre-/post-fire ratios. Then, the scaled index of burn severity, named differenced Normalised Burn Ratio (dNBR) (Key \& Benson, 2005), was assessed. This index has been used worldwide in many different environments (Van Wagtendonk et al., 2004; Cocke et al., 2005; Epting et al., 2005; Gitas et al., 2012; Veraverbeke et al., 2011), and using the following equation:

$$
d N B R=N B R_{\text {pre }}-N B R_{\text {post }}
$$

The dNBR values were classified from the USGS FIREMON program (USGS, 2004) shown in Table I. Generally, unburned areas (i.e. no change between pre and post-fire scenarios) have dNBR values near zero; whereas the higher positive values corresponded to the more 
severely burned areas (i.e. fire changed them the most). As burned vegetation was quickly removed after the fire, validation of the burn severity levels at field conditions was not possible. We took pictures of the burned area as soon as the authorities allowed entrance, and used this data as an alternative supervised method of validation.

\section{Modelling of hydrological connectivity}

We used the index of runoff and sediment connectivity (IC) proposed by Borselli et al. (2008) as well as part of the modifications made on it by Cavalli et al. $(2013,2015)$. The $D_{d n}$ factor (downslope module) considers the probability that runoff and sediment arrives at a sink along a flow line, whereas the $D_{u p}$ factor (upslope module) summarizes the potential for downward routing of the overland flow produced upslope and expands the same analysis to an area:

$$
I C_{K}=\log _{10}\left(\frac{D_{u p, K}}{D_{d n, K}}\right)=\log _{10}\left(\frac{\overline{W_{K}} \cdot \overline{S_{K}} \cdot \sqrt{A_{K}}}{\sum_{i=K, n_{K}} \frac{d_{i}}{W_{i} \cdot S_{i}}}\right)
$$

where $A$ is the upslope contributing area $\left(\mathrm{m}^{2}\right), \bar{W}$ is the average weighting factor of $A$ (dimensionless), $\bar{S}$ is the average slope gradient of $A\left(\mathrm{~m} \mathrm{~m}^{-1}\right), d_{i}$ is the length of the $i$ th cell along the downslope path (m), $W_{i}$ is the weight of the $i$ th cell (dimensionless), and $S_{i}$ is the slope gradient of the $i$ th cell $\left(\mathrm{m} \mathrm{m}^{-1}\right)$. The $W$ weighting factor is a proxy of the impedance to sediment fluxes that is based on land use properties. Values of $S_{i}$ lower than 0.005 must be replaced by the value $S_{i}=0.005$ and those higher than 1 must be set to a maximum value of 1. This index is defined in the range of $[-\infty,+\infty]$ and connectivity increases when $I C$ grows towards $+\infty$.

In the original version as well as in other studies, the $W$ factor was equal to the $C-R U S L E$ factor. In this study, we chose the product between the C-RUSLE factor, and the maps of burn severity, salvage logging and the different levels of vegetation recovery after the fire. In $I C$, the role of the linear landscape elements (LLE) is added to the simulation by modifying the map of flow direction: a mask with two values, 0 for the LLE and 1 for the remaining area (Table II).

The weighted flow path length, the $\underline{W}, \underline{S}$ and $A$ factors were calculated with the D-infinity flow accumulation algorithm (Tarboton, 1997) that is available in the software $S A G A^{\circledR}-64$ 2.1.2. This approach is recommended for sediment transport studies in mountainous basins 

tools for the analysis of hydrologic information from topography (Tarboton, 2013). The Dinfinity method captures the real flow paths especially on hillslopes where divergent flow predominates, and it better approximates channel width than the D8 single flow and the MD multiple flow direction methods. Finally, the IC model includes the "stream mask" layer that is associated with the presence of permanent and ephemeral streams. Different "stream mask" layers were associated with the pre-fire and post-fire gully networks as well as with the construction of the check-dams and their stage (non-silted, partially and completely silted).

Pre-fire and post-fire scenarios

210 Table II and figure 2 show the eight simulated scenarios. A pre-fire (PreF) scenario was 211 modelled in order to compare the post-fire and future scenarios to the previous conditions. 212 After the wildfire occurred, five scenarios were defined based on the observed vegetation and 213 landscape changes, and on the different management done in the affected area. The first post214 fire (PostF-1) scenario only considered the loss of vegetation due to the wildfire. The effect 215 of salvage logging and construction of new check-dams and skid trails were included in the second (PostF-2) and subsequent scenarios. Two stages for the incipient and progressive vegetation recovery were considered in the fourth (PostF-4) and fifth (PostF-5) post-fire scenarios. Changes related to the stream network were included from PostF-3 on, due to the growth of the gully system with new gullies and the clear lengthening of the previous gullies. The construction of the 23 new check-dams (12 made on wood and 11 with concrete) in the main streams were included in the stream maps, taking into account their evolution, from empty (PostF-2, -3 and -4 scenarios), to partially (PostF-5 scenario) and completed silted (future scenarios) conditions. Additionally, two potential future scenarios were simulated in order to provide valuable information to the stakeholders and the local and regional authorities. These scenarios were associated with a poor and a good recovery of the natural vegetation within the burned area, and were linked to the expected vegetation recolonization at short- (ca. 5 years) and long- (more than 10 years) term. We did not include other potential future changes, such as vegetation mortality, new roads or the growth of the sub-urban areas in order to minimize the variability in the inputs of the simulated scenarios.

Model parameterization 

performed at this spatial resolution. Before running the $I C$ model, the continuity of the flow path lines was ensured by removing the local depressions and artifacts of the DEM. We used the algorithm of Planchon \& Darboux (2001) $\left(S A G A^{\circledR}\right.$-64 2.1.2) that preserved a minimum slope gradient of 0.01 degree. Then, the boundaries of the eleven sub-catchments (SubC) were calculated upwards from the defined outlets $\left(\operatorname{Arc} G I S^{\oplus} 10.3\right)$.

Seven maps of vegetation cover ( $W$ factor) were generated using the maps of pre-fire land uses $\left(Q G I S^{\odot}\right.$-64 2.14.0-Essen), burn severity and salvage logging, and the four levels of vegetation recovery. The pre-fire land cover information was taken from the "Red de Información Ambiental de Andalucía"

Database

244 (http://www.juntadeandalucia.es/medioambiente/site/rediam). The values of the C-RUSLE factor for the different pre-fire land uses were obtained from Gómez et al. (2003), Miller et al. (2003), López-Vicente \& Navas (2009) and Panagos et al. (2015). The post-fire C-RUSLE parameterization (PostF-1 scenario) was done by multiplying the pre-fire C-RUSLE map with the weighted map of burn severity classes, the field-identified wildfire limit and the weighting values proposed by Larsen \& MacDonald (2007) and Yochum \& Norman (2015): low burn $=1.10$, moderate burn $=2.25$ and high burn $=3.75$. These authors didn't estimate extreme burn severity changes. Thus, we selected a new value (5.25) for this fire level using professional judgment. The consequence of salvage logging (PostF-2 scenario) was simulated considering an average original canopy cover of $40 \%$ of the trees on the burned areas. On the basis of field observations and pictures, the effect of the incipient vegetation recovery was simulated in the scenarios PostF-4 and -5 considering a 10 and $15 \%$ decrease in the values of the $W$-PostF-2 map within the burned area. The poor and good vegetation recovery of the Fut-1 and -2 scenarios corresponded to a 25 and $75 \%$ decrease in the values of the W-PostF-2 map. The two maps of the LLE included the roads, trails, new skid trails and the main streets of the urban area (Table II). Five stream masks were mapped considering the temporal changes in the gullies (pre- and post-fire), the construction of the check-dams and their effectiveness (non-silted, partially and completely silted) to reduce runoff and sediment delivery. The location of the beginning and ending points of the buried pipes in the urban area of the SubC4, -6 and -7 were identified by field survey and included in the stream maps. Along the pipes, the main streams flow underground, and thus these sections were removed from the gully network. 
269 The HC from the different scenarios was validated by means of two procedures. Firstly, a 270 photo-interpretation process was performed using high resolution Digital Globe images 271 downloaded from Google Earth; its spatial resolution (1x1 m) was sufficient to draw the post272 fire drainage network of rills and gullies and thus evaluate the actual connection between the 273 top of hillslopes to the bottom and channels. And secondly, several field surveys were 274 conducted in the study area in order to checking that photo-interpretation, the land use and

275 276 277 278 279 280

\section{RESULTS AND DISCUSSION}

\section{Mapping of burn severity}

Figure 3 shows the burn severity map obtained from the dNBR calculation. The burn severity was spatially variable covering all the burn severity classes according to USGS (2007). Some unburned areas were observed within the wildfire limit but represented less than $6 \%$ of the total area (Table III). More than the $50 \%$ of the burned area was classified as low and lowmoderate severity burn class, whereas less than $10 \%$ corresponded to high/extreme severity. The extreme burn severity was obtained for those pixels with major vegetation cover in the pre-fire scenario and in the SubC-1, -7, -8 and -9 .

In Figure 3, the rill and gully network developed after the wildfire were also included. At a glance, no spatial relations were observed between burn severity class and the formation of rills and gullies. All of them were formed or crossed areas classified in all of the burn severity classes. This situation may be indicating the burn severity were not the most influential factor in the post-fire erosion processes. This is not the case of the salvage logging carried out after the wildfire, which enhanced the formation of many new rills and gullies as it will be presented later.

\section{Evolution of the hydrological connectivity}

The values and spatial patterns of $\mathrm{HC}$ clearly changed over the eight scenarios and throughout the study area (Figure 4). On the basis of the PreF scenario, the overall values of $\mathrm{HC}$ increased during the three initial post-fire scenarios, reaching the highest values of connectivity in PostF-3 (Table IV). From PostF-3 on, connectivity slightly decreased during the two most recent post-fire scenarios and more clearly during the two potential future 
scenarios. These changes were greater within the burned area, reaching an increment of $26 \%$ of HC during PostF-3. This trend was constant in all sub-catchments except in the SubC-2, -4 and -5 due to the small burned area within these SubC, lower than $2 \%$, and the high percentage of urban areas, higher than 47\%, in SubC-4 and -5 (Figure 5a). In order to refine the analysis of the evolution in the values of $\mathrm{HC}$, we distinguished four types of SubC: (I) forestry with check-dams and large burned area, (II) urban and small burned area, (III) urban and large burned area, and (IV) forestry without check-dams and small burned area (Table III). The two SubC-IV had the lowest impact of human activities, whereas the other three types of SubC presented different human-activity impact. The evolution in the values of HC was clearly different in each type of SubC. Wildfire (PostF-1) produced an increase of 11.4, $4.4,3.0$ and $2.5 \%$ in the values of HC in the SubC-I, II, III and IV, respectively, whereas salvage logging and the new skid trails (PostF-2) triggered an increase of 18.2, -4.3, 8.2 and 4.6\%. The construction of check-dams in this scenario was not enough to stop the overall increase of HC. These changes were greater in SubC-1 and -7 where extreme burn severity affected the forest, and the increase of $\mathrm{HC}$ immediately after the fire was of $12.4 \%$ on average. These results agreed with those reported by Moody et al. (2008) after analysing the runoff response in mountainous watersheds affected by different burn severity levels.

The development of new gullies (PostF-3) explained the increment up to 22.9, -4.3, 9.1 and $6.3 \%$ in the values of connectivity in the SubC-I, II, III and IV related to the PreF scenario. The decrease of connectivity in the SubC-II was explained by their high density of LLE (roads and streets, see Figure 2) that acted as effective downslope and lateral route, and thus connecting the hillslopes of the different SubC between them. The incipient vegetation recovery in the burned areas (PostF-4) provided a 2.5, 0.05, 1.3 and 1.0\% decrease of connectivity in the SubC-I, II, III and IV, respectively, related to the PostF-3 scenario. The effectiveness of the small (PostF-5) and future $(F u t-1,-2)$ vegetation recovery reducing the values of $\mathrm{HC}$ was greater than the role played by the partially and silted check-dams increasing the connectivity values. In Fut-2, lower values of $\mathrm{HC}$ than those obtained during PreF were predicted in SubC-II, III and IV, and still higher values in SubC-I. This fact was explained by the methodology used to modify the $W$ factor, considering a homogeneous recovery of the vegetation in the burned areas. Following this approach, we obtained lower values of the $W$ factor (higher vegetation density) in same patches of the hillslopes than those values assigned in the pre-fire scenario. In spite of the different evolution of connectivity obtained between the different types of SubC, we found the same evolution when the analyses was limited to the burned area (Figure $5 b$ ). 
338 The effect of the different post-fire practices on connectivity was assessed by means of analysing the evolution of the values of $\mathrm{HC}$ in the different geomorphic features of each SubC and during the eight scenarios. Changes of HC in the LLE (Figure 5c) mirrored the general patterns described at SubC scale, although the skid trails construction (PostF-2)

342 triggered an increase of HC of $43.2 \%$ in the LLE of the four affected SubC (\# 1, 7, 8 and 9)

343 whereas the average increase of $\mathrm{HC}$ in these SubCs was of $16.6 \%$. Additionally, the 344 expansion of the gully system (PostF-3) did not produce any effect on the values of HC in the 345 LLE. Connectivity at the outlets of the SubC showed a different behaviour, decreasing significantly after the wildfire, increasing a little with the post-fire practices and remaining almost stable during the vegetation recovery, except in Fut-2 when HC decreased. This evolution may be explained because the outlets are located far from the burned areas, by the short-distance effect of the changes in HC due to the wildfire, and by the creation of many new routes of connectivity within the hillslopes that are located upslope the outlets (Figure $5 d)$.

The evolution of connectivity in the ephemeral streams (Figure 5e) and gullies (Figure 5f) showed the same patterns as those described in the burned areas in SubC-I, although the magnitude of the changes was greater in the gullies, especially during PostF-3 with the emergence of new gullies. In SubC-II, III and IV, changes of HC in the gullies were similar to the general trend, reaching the highest values of connectivity in PostF-3, and decreasing from that scenario on. However, the changes of HC in the ephemeral streams in SubC-II, III and IV were contrary. These apparently contradictory results may be explained by the mean length of the effective flow path lines in the different SubC during the eight scenarios. The different characteristics of each type of SubC caused different changes in the values and patterns of HC. These results agree with those reported by Ferreira et al. (2008) who found that land use patterns play a crucial role in reducing or enhancing the hydrological and sediment yield processes.

Further research and suggested practices

366 In order to refine the proposal of the best scenario to reduce the values of runoff and sediment connectivity in the burned area, we will estimate in further research the alone effect of each change (burned forest, salvage logging, new skid trails, new gullies, new check-dams and 
October 2016 (Figure 6). We will also refine the map of the vegetation recovery, accounting

371

372

373

374

375

376

377

378

379

380

381

382

383

384

385

386

387

388

389

390

391

392

393

394

395

396

397

398

399

400

401

402

403 the actual potential regrowth in the different patches of the landscape, year by year after the wildfire.

Another remarkable consideration to take into account, maybe the most important in the study area, is the effect of salvage logging. This procedure is frequently conducted in some burned areas with the main purposes of inhibiting plagues and reducing the risk of falls. However, this task extremely disturbed the scarce soil of the study area, enhanced rilling and gullying. It has been widely investigated that salvage logging contribute to soil degradation and post-fire erosion processes (Wagenbrenner et al., 2015; Fernández \& Vega, 2016). Thus, the effects of post-fire management should be balanced before proceeding to carry it out.

To minimize the off-site effect of vegetation depletion, several check-dams were built in the main streams. Only with one rainwash event $(60.0 \mathrm{~mm}$ in 6 hours $)$ occurred three months after the wildfire (PostF-3), most of the check-dams were almost silted; many of them are now fully silted after 2.5 years and only the major one is partially silted. Both these field data and the simulation results of this study demonstrated that there is a very high connectivity along the burned sub-catchments, enhanced by the rills and gullies which easily connect hillslopes with channels. Check-dams played a remarkable but short effective role in slowing down delivery processes and off-site effects. The very low recovery of vegetation in this type of soils as well as consequence of the salvage logging is now producing a positive feedback of overland flow and sediment transport from headwaters to off-site. Thus, it is necessary to carry out some post-fire erosion management in hillslopes.

\section{CONCLUSIONS}

This study revealed salvage logging after a wildfire might be considered as a more influential factor than, for instance, burn severity enhancing the hydrological connectivity in the hillslope-catchment system. Namely, the conclusions are the following:

i) Considering different pre- and post-fire scenarios, the modelling of hydrological connectivity at high spatial resolution using the D-Infinity algorithm as well as modifying the values of C-RUSLE by the burn severity was satisfactory.

ii) In the modelled scenarios, the hydrological connectivity increased after the wildfire, independently of burn severity, and, especially, when skid trails as well as salvage logging were carried out, triggering new rills and gullies in the most burned sub-catchments, despite check-dams reduced that connectivity at short-distance. Only the hydrological connectivity 
404

405

406

407

408

409

410

411

412

413

414

415

416

417

418

419

420

421

422

423

424

425

426

427

428

429

430

431

432

433

434

435

436

437

was reduced when a certain recovery of vegetation cover was considered in two future scenarios. These changes were especially observed within the gully system but not always in the ephemeral streams and outlets.

iii) The modelling was satisfactorily validated with aerial and field observations of concentrated (rills, gullies and ephemeral streams), dispersed (hillslopes) and blocked (checkdams) overland flow. The linear landscape elements, such as trails, skid trails, roads and streets connected the hillslopes of the different sub-catchments between them. This process explained either the small decrease of hydrological connectivity in the three subcatchments with large urban area and small burned area or the increase in sub-catchments with major burned areas.

iv) Salvage logging implied the removal of burned vegetation and the opening of new skid trails without considering mitigation techniques to be performed in hillslopes and not only in channels (building of check-dams). In further researches, monitoring of check-dam siltation and of the actual vegetation regrowth following a patched design is necessary and recommended to minimize the current and future off-site consequences of high hydrological connectivity, especially, in those sub-catchments containing burned wildland-urban interface.

\section{ACKNOWLEDGMENTS}

The authors are grateful to the Plan Propio de Investigación y Transferencia from the Universidad de Málaga for its financial support. This study was done in the frame of the European COST action ES1306 “Connecteur”: Connecting European Connectivity Research.

\section{REFERENCES}

Bodí M, Cerdà A, Mataix-Solera J, Doerr SH. 2012. Efectos de los incendios forestales en la vegetación y el suelo en la cuenca mediterránea: revisión bibliográfica. Boletín de la Asociación de Geógrafos Españoles $\mathbf{5 8}$ $33-35$.

Borselli L, Cassi P, Torri D. 2008. Prolegomena to sediment and flow connectivity in the landscape: A GIS and field numerical assessment. Catena 75 (3): 268-277. DOI:10.1016/j.catena.2008.07.006.

Bracken LJ, Croke J. 2007. The concept of hydrological connectivity and its contribution to understanding runoff-dominated geomorphic systems. Hydrological Processes 21: 1749-1763. DOI:10.1002/hyp.6313.

Cannon SH, Gartner JE. 2005. Wildfire-related debris flow from a hazards perspective. In: Hungr O, Jacob M (Eds.), Debris Flows and Debris Avalanches - The State of the Art. Springer Verlag, Berlin, pp. 365-385.

Cavalli M, Crema S, Marchi L. 2015. Guidelines on the Sediment Connectivity stand-alone application SedInConnect. Release: 2.0 and 2.1 [online] Available from: https://github.com/HydrogeomorphologyTools. 
Cavalli M, Trevisani S, Comiti F, Marchi L. 2013. Geomorphometric assessment of spatial sediment connectivity in small Alpine catchments. Geomorphology 188: 31-41. DOI:10.1016/j.geomorph.2012.05.007.

441

442

443

444

445

446

447

448

449

450

451

452

453

454

455

456

457

458

459

460

461

462

463

464

465

466

467

468

469

470

471

472

473

474

475

476

477

Chartin C, Evrard O, Onda Y, Patin J, Lefèvre I, Ottlé C, Ayrault S, Lepage H, Bonte P. 2013. Tracking the early dispersion of contaminated sediment along rivers draining the Fukushima radioactive pollution plume. Anthropocene 1: 23-34. DOI:10.1016/j.ancene.2013.07.001.

Chavez PS. 1996. Image-based atmospheric corrections. Revisited and improved. Photogrammetric Engineering and Remote Sensing 62: 1025-1036.

Cocke AE, Fulé PZ, Crouse JE. 2005. Forest change on a steep mountain gradient after extended fire exclusion: San Francisco Peaks, Arizona, USA. Journal of Applied Ecology 42 (5): 814-823. DOI:10.1111/j.13652664.2005.01077.x.

Epting J, Verblya D, Sorbel B. 2005. Evaluation of remotely sensed indices for assessing burn severity in interior Alaska using Landsat TM and ETMp. Remote Sensing of Environment 96 (3-4): 328-339. http://dx.doi.org/10.1016/j.rse.2005.03.002.

Estrany J, López-Tarazón JA, Smith HG. 2016. Wildfire effects on suspended sediment delivery quantified using fallout radionuclide tracers in a Mediterranean catchment. Land Degradation \& Development 27: 1501-1512. DOI:10.1002/ldr.2462.

Fernández C, Vega JA. 2016. Effects of mulching and post-fire salvage logging on soil erosion and vegetative regrowth in NW Spain. Forest Ecology and Management 375: 46-54. DOI:10.1016/j.foreco.2016.05.024.

Ferreira AJD, Coelho COA, Ritsema CJ, Boulet AK, Keizer JJ. 2008. Soil and water degradation processes in burned areas: Lessons learned from a nested approach. Catena $\mathbf{7 4}$ (3): 273-285. DOI:10.1016/j.catena.2008.05.007.

Ferreira CSS, Walsh RPD, Nunes JPC, Steenhuis TS, Nunes M, de Lima JLMP, Coelho COA, Ferreira AJD. 2016. Impact of urban development on streamflow regime of a Portuguese peri-urban Mediterranean catchment. Journal of Soils and Sediments 11: 2580-2593. DOI: 10.1007/s11368-016-1386-5.

Foerster S, Wilczok C, Brosinsky A, Segl K. 2014. Assessment of sediment connectivity from vegetation cover and topography using remotely sensed data in a dryland catchment in the Spanish Pyrenees. Journal of Soils and Sediments 14: 1982-2000. DOI:10.1007/s11368-014-0992-3.

Garcia ML, Caselles V. 1991. Mapping burns and natural reforestation using Thematic Mapper data. Geocarto International 6 (1): 31-37. DOI:10.1080/10106049109354290.

Gay A, Cerdan O, Mardhel V, Desmet M. 2016. Application of an index of sediment connectivity in a lowland area. Journal of Soils and Sediments 16 (1): 280-293. DOI:10.1007/s11368-015-1235-y.

Gitas I, Mitri I, Veraverbeke S, Polychronaki A. 2012. Advances in remote sensingof post-fire vegetation recovery monitoring - a review. In: Fatoyinbo, L. (Ed.), Remote Sensing of Biomass - Principles and Applications. InTech.

Gómez JA, Battany M, Renschler CS, Fereres E. 2003. Evaluating the impact of soil management on soil loss in olive orchards. Soil Use and Management 19 (2): 127-134. DOI:10.1111/j.1475-2743.2003.tb00292.x.

Heckmann T, Schwanghart W. 2013. Geomorphic coupling and sediment connectivity in an alpine catchment exploring sediment cascades using graph theory. Geomorphology 182: 89-103. DOI:10.1016/j.geomorph.2012.10.033. 
Key CH, Benson NC.2005. Landscape assessment: ground measure of severity; the Composite Burn Index, and remote sensing of severity, the Normalized Burn Index. In D. Lutes, R. Keane, J. Caratti, C. Key, N. Benson, S. Sutherland, et al. (Eds.), FIREMON: Fire effects monitoring and inventory system (pp. 1-51). Forest Service, Rocky Mountains Research Station: USDA. General Technical Report RMRS-GTR-164-CD LA.

Larsen IJ, MacDonald LH. 2007. Predicting postfire sediment yields at the hillslope scale: Testing RUSLE and Disturbed WEPP. Water Resources Research 43: W11412. DOI:10.1029/2006WR005560.

Lein JK, Stump NI. 2009. Assessing wildfire potential within the wildland-urban interface: A southeastern Ohio example. Applied Geography 29: 21-34. DOI: 10.1016/j.apgeog.2008.06.002.

López-Vicente M, Lana-Renault N, García-Ruiz JM, Navas A. 2011. Assessing the potential effect of different land cover management practices on sediment yield from an abandoned farmland catchment in the Spanish Pyrenees. Journal of Soils and Sediments 11 (8): 1440-1455. DOI:10.1007/s11368-011-0428-2.

López-Vicente M, Nadal-Romero E, Cammeraat ELH. 2016. Hydrological connectivity does change over 70 years of abandonment and afforestation in the Spanish Pyrenees. Land Degradation \& Development: DOI:10.1002/ldr.2531.

López-Vicente M, Navas A. 2009. Predicting soil erosion with RUSLE in Mediterranean agricultural systems at catchment scale. Soil Science 174 (5): 272-282. DOI:10.1097/SS.0b013e3181a4bf50.

López-Vicente M, Poesen J, Navas A, Gaspar L. 2013. Predicting runoff and sediment connectivity and soil erosion by water for different land use scenarios in the Spanish Pre-Pyrenees. Catena 102: 62-73. DOI:10.1016/j.catena.2011.01.001.

Malvar MC, Prats S, Nunes JP, Keizer JJ. 2016a. Soil water repellency severity and its spatio-temporal variation in burnt Eucalypt plantations in North-Central Portugal. Land Degradation \& Development 27 (5): 14631478. DOI:10.1002/ldr.2450.

Malvar MC, Prats SA, Keizer JJ. 2016b. Runoff and Inter-Rill Erosion Affected by Wildfire and Pre-Fire Ploughing in Eucalypt Plantations of North-Central Portugal. Land Degradation \& Development 27 (5): 1366-1378. DOI:10.1002/ldr.2365.

Martínez-Murillo JF, Hueso-González P, Ruiz-Sinoga JD, Lavee H. 2016a. Short-term experimental fire effects in soil and water losses in Southern of Spain. Land Degradation \& Development 27 (5): 1513-1522. DOI:10.1002/ldr.2504.

Martínez-Murillo JF, Neris J, Hyde K, Keizer JJ. 2016b. Advances towards an integrated assessment of fire effects on soils, vegetation and geomorphological processes. Land Degradation \& Development 27 (5): 1314-1318. DOI:10.1002/ldr.2520.

Miller JD, Nyhan JW, Yool SR. 2003. Modeling potential erosion due to the Cerro Grande Fire with a GISbased implementation of the Revised Universal Soil Loss Equation. International Journal of Wildland Fire 12: 85-100. DOI:10.1071/WF02017.

Moody JA, Martin DA, Haire SL, Kinner DA. 2008. Linking runoff response to burn severity after a wildfire. Hydrological Processes 22 (13): 2063-2074. DOI:10.1002/hyp.6806.

Panagos P, Borrelli P, Meusburger K, Alewell C, Lugato E, Montanarella L. 2015. Estimating the soil erosion cover-management factor at the European scale. Land Use Policy 48: 38-50. DOI:10.1016/j.landusepol.2015.05.021. 
517 Planchon O, Darboux F. 2001. A fast, simple and versatile algorithm to fill the depressions of digital elevation

518 models. Catena 46 (2-3): 159-176. DOI:10.1016/S0341-8162(01)00164-3.

519 Prats SA, Wagenbrenner J, Martins MAS, Malvar MC, Keizer JJ. 2016. Hydrologic implications of post-fire mulching across different spatial scales. Land Degradation \& Development 27 (5): 1440-1452. DOI:10.1002/ldr.2422.

Reaney SM, Bracken LJ, Kirkby MJ. 2014. The importance of surface controls on overland flow connectivity in semi-arid environments: Results from a numerical experimental approach. Hydrological Processes 28 (4): 2116-2128. DOI:10.1002/hyp.9769.

Robichaud PR. 2000. Fire effects on infiltration rates after prescribed fire in Northern Rocky Mountain forests, USA. Journal of Hydrology 231-232: 220-229. DOI:10.1016/S0022-1694(00)00196-7.

Robichaud PR, Lewis SA, Wagenbrenner JW, Ashmun LE, Brown RE. 2013. Post-fire mulching for runoff and erosion mitigation. Part I: effectiveness at reducing hillslope erosion rates. Catena 105: 75-92. DOI:10.1016/j.catena.2012.11.015.

Shakesby RA. 2011. Post-wildfire soil erosion in the Mediterranean: review and future research directions. Earth-Science Reviews 105 (3-4): 71-100. DOI:10.1016/j.earscirev.2011.01.001.

Shakesby RA, Doerr SH. 2006. Wildfire as a hydrological and geomorphological agent. Earth Science Reviews 74 (3-4): 269-307. DOI:10.1016/j.earscirev.2005.10.006.

Tarboton DG. 1997. A new method for the determination of flow directions and upslope areas in grid digital elevation models. Water Resources Research 33 (2): 309-319. DOI:10.1029/96WR03137.

Tarboton DG. 2013. TauDEM 5.1, Terrain Analysis Using Digital Elevation Models [online] Available from: http://hydrology.usu.edu/taudem/taudem5/

Turnbull L, Wainwright J, Brazier RE. 2008. A conceptual framework for understanding semi-arid land degradation: ecohydrological interactions across multiple-space and time scales. Ecohydrology 1: 23-34. DOI:10.1002/eco.4.

USGS 2004

\section{FIREMON}

BR Cheat

V4 [Online].

Available http://burnseverity.cr.usgs.gov/pdfs/LAv4_BR_CheatSheet.pdf Accessed 06.07.2016.

USGS. 2007. Burn severity overview e Applied remote sensing Principles [Online]. Available http://burnseverity.cr.usgs.gov/overview/nbr/index.php Accessed 06.07.2016.

545 Van Wagtendonk JW, Root RR, Key CH. 2004. Comparison of AVIRIS and Landsat ETMp detection capabilities for burn severity. Remote Sensing of Environment

92 (3): 397-408. http://dx.doi.org/10.1016/j.rse.2003.12.015.

Veraverbeke S, Lhermitte S, Verstraeten WW, Goossens R. 2011. A time integrated MODIS burn severity assessment using the multi-temporal differenced Normalized Burn Ratio (dNBRMT). International Journal of Applied Earth Observation http://dx.doi.org/10.1016/j.jag.2010.06.006.

Wagenbrenner JW, MacDonald LH, Coats RN, Robichaud PT, Brown RE. 2015. Effects of post-fire salvage logging and a skid trail treatment on ground cover, soils, and sediment production in the interior western

and Management

335: $\quad$ 176-193. http://dx.doi.org/10.1016/j.foreco.2014.09.016. 
Wagenbrenner JW, Robichaud PT, Brown RE. 2016. Rill erosion in burned and salvage logged western montane forests: Effects of logging equipment type, traffic level, and slash treatment. Journal of Hydrology 541: 889901. http://dx.doi.org/10.1016/j.jhydrol.2016.07.049.

559 Wainwright J, Turnbull L, Ibrahim TG, Lexartza-Artza I, Thornton SF, Brazier R. 2011. Linking environmental 560 regimes, space and time: interpretations of structural and functional connectivity. Geomorphology 126 (3-4): 561 387-404. http://dx.doi.org/10.1016/j.geomorph.2010.07.027.

562 Yochum SE, Norman JB. 2015. Wildfire-induced flooding and erosion-potential modeling: Examples from 563 Colorado, 2012 and 2013. In: Proceedings of the 3rd Joint Federal Interagency Conference on Sedimentation 564 and Hydrologic Modeling, April 19-23, 2015, Reno, Nevada, USA. 
566 Table I. The scaled index of burn severity based on values derived from the USGS

567 FIREMON program (USGS, 2007).

\begin{tabular}{|l|l|}
\hline dNBR & Burn Severity class \\
\hline$<-0.25$ & High post-fire regrowth \\
\hline-0.25 to -0.10 & Low post-fire regrowth \\
\hline-0.10 to +0.10 & Unburned \\
\hline 0.10 to 0.27 & Low severity \\
\hline 0.27 to 0.44 & Moderate-low severity \\
\hline 0.44 to 0.66 & Moderate-high severity \\
\hline$>0.66$ & High severity \\
\hline
\end{tabular}


Table II. Date and characteristics of the eight simulated scenarios. LLE: linear landscape elements; T: trails; R:

571 roads; St: streets; S-T: skid trails; EpS: ephemeral streams; Gu: gullies; BP: buried pipes; and C-D: check-dams.

\begin{tabular}{|c|c|c|c|c|c|}
\hline \multicolumn{3}{|c|}{ Scenario } & \multirow[t]{2}{*}{ Vegetation maps } & \multicolumn{2}{|c|}{ Flow direction map features } \\
\hline Date & Name & Description & & LLE & Stream mask \\
\hline 2012 & PreF & Before the fire & C-2012 & $\mathrm{T}, \mathrm{R}, \mathrm{St}$ & EpS, Gu and BP \\
\hline $\begin{array}{l}\text { 28-Jun- } \\
2014\end{array}$ & PostF-1 & $\begin{array}{l}\text { Immediately after } \\
\text { the fire }\end{array}$ & $\begin{array}{l}\text { C-2012 + Burn } \\
\text { severity }\end{array}$ & $\mathrm{T}, \mathrm{R}, \mathrm{St}$ & EpS, Gu and BP \\
\hline $\begin{array}{l}\text { Sep- } \\
2014\end{array}$ & PostF-2 & $\begin{array}{l}\text { First management } \\
\text { practices }\end{array}$ & $\begin{array}{l}\text { C-2012 + Burn } \\
\text { severity }+ \\
\text { Salvage logging }\end{array}$ & $\begin{array}{l}\mathrm{T}, \mathrm{R}, \mathrm{St} \text { and } \\
\text { new S-T }\end{array}$ & EpS, Gu, BP and C-D \\
\hline $\begin{array}{l}\text { Oct- } \\
2014\end{array}$ & PostF-3 & $\begin{array}{l}\text { Development of } \\
\text { new rills and gullies }\end{array}$ & $\begin{array}{l}\text { C-2012 + Burn } \\
\text { severity }+ \\
\text { Salvage logging }\end{array}$ & $\begin{array}{l}\mathrm{T}, \mathrm{R}, \mathrm{St} \text { and } \\
\text { new S-T }\end{array}$ & $\begin{array}{l}\text { EpS, Gu, BP, new Gu and } \\
\text { C-D }\end{array}$ \\
\hline 2015 & PostF-4 & $\begin{array}{l}\text { Incipient vegetation } \\
\text { recovery }\end{array}$ & $\begin{array}{l}\text { C-2012 + Burn } \\
\text { severity + Veg. } \\
\text { recov. } 10 \%\end{array}$ & $\begin{array}{l}\mathrm{T}, \mathrm{R}, \mathrm{St} \text { and } \\
\text { new S-T }\end{array}$ & $\begin{array}{l}\text { EpS, Gu, BP, new Gu and } \\
\text { C-D }\end{array}$ \\
\hline $\begin{array}{l}\text { Oct- } \\
2016\end{array}$ & PostF-5 & $\begin{array}{l}\text { Check-dams } \\
\text { partially silted }\end{array}$ & $\begin{array}{l}\text { C-2012 + Burn } \\
\text { severity + Veg. } \\
\text { recov. } 15 \%\end{array}$ & $\begin{array}{l}\mathrm{T}, \mathrm{R}, \mathrm{St} \text { and } \\
\text { new S-T }\end{array}$ & $\begin{array}{l}\text { EpS, Gu, BP, new } \mathrm{Gu} \text { and } \\
\text { C-D partially silted }\end{array}$ \\
\hline $\begin{array}{l}\text { Future: } \\
\text { Short- } \\
\text { term }\end{array}$ & Fut-1 & $\begin{array}{l}\text { All check-dams } \\
\text { silted and poor } \\
\text { vegetation recovery }\end{array}$ & $\begin{array}{l}\text { C-2012 + Burn } \\
\text { severity + Veg. } \\
\text { recov. } 25 \%\end{array}$ & $\begin{array}{l}\mathrm{T}, \mathrm{R}, \mathrm{St} \text { and } \\
\text { new S-T }\end{array}$ & $\begin{array}{l}\text { EpS, } \mathrm{Gu}, \mathrm{BP} \text {, new } \mathrm{Gu} \text { and } \\
\text { all C-D silted }\end{array}$ \\
\hline $\begin{array}{l}\text { Future: } \\
\text { Long- } \\
\text { term }\end{array}$ & Fut-2 & $\begin{array}{l}\text { All check-dams } \\
\text { silted and good } \\
\text { vegetation recovery }\end{array}$ & $\begin{array}{l}\text { C-2012 + Burn } \\
\text { severity + Veg. } \\
\text { recov. } 75 \%\end{array}$ & $\begin{array}{l}\mathrm{T}, \mathrm{R}, \mathrm{St} \text { and } \\
\text { new S-T }\end{array}$ & $\begin{array}{l}\text { EpS, } \mathrm{Gu}, \mathrm{BP} \text {, new } \mathrm{Gu} \text { and } \\
\text { all C-D silted }\end{array}$ \\
\hline
\end{tabular}


574 Table III. Surface percentage occupied by each burn severity class according to the satellite 575 images (see Figure 3); and percentage of burned (BA) and urban areas within each sub576 catchment. Type I: forest with check-dams and large BA; Type II: urban and small BA; Type 577 III: urban and large BA; Type IV: forest without check-dams and small BA.

\begin{tabular}{|c|c|c|c|c|c|c|c|c|c|c|c|c|}
\hline \multirow[t]{3}{*}{ Burn severity class } & \multirow{3}{*}{$\begin{array}{l}\text { Burned } \\
\text { area } \\
(\%)\end{array}$} & \multicolumn{11}{|c|}{ Sub-catchment number and type, and burned area $(\%)$} \\
\hline & & 1 & 2 & 3 & 4 & 5 & 6 & 7 & 8 & 9 & 10 & 11 \\
\hline & & I & II & III & II & II & III & I & III & I & IV & IV \\
\hline Urban areas & - & 1.0 & 10.4 & 28.2 & 47.3 & 86.9 & 32.1 & 12.5 & 31.2 & 4.4 & 1.6 & 0.4 \\
\hline Unburned & 5.7 & 11.9 & 99.1 & 77.5 & 98.1 & $100^{*}$ & 50.5 & 30.0 & 58.2 & 24.3 & 71.2 & 63.4 \\
\hline Low / Very low & 28.8 & 18.7 & 0.9 & 10.1 & 1.0 & - & 25.9 & 22.7 & 24.7 & 21.0 & 14.6 & 23.5 \\
\hline Moderate-low / Low & 40.1 & 43.9 & - & 11.5 & 0.9 & - & 22.2 & 28.8 & 15.0 & 38.8 & 10.8 & 12.7 \\
\hline Moderate-high / Moderate & 18.6 & 23.4 & - & 0.9 & - & - & 1.5 & 10.3 & 1.6 & 15.4 & 3.4 & 0.4 \\
\hline High / Extreme & 6.8 & 2.0 & - & - & - & - & - & 8.2 & 0.4 & 0.4 & - & - \\
\hline Total burned area & 100.0 & 88.1 & 0.9 & 22.5 & 1.9 & $0 *$ & 49.5 & 70.0 & 41.8 & 75.7 & 28.8 & 36.6 \\
\hline
\end{tabular}

578 *: a small burned area was identified in the field survey, smaller than the pixel resolution of the satellite images. 
Table IV. Values and changes $(\delta)$ of hydrological connectivity $(\mathrm{HC})$ obtained at the eight simulated scenarios.

582 LLE: linear landscape elements; TL: total length; *: related to the pre-fire scenario; **: related to the previous scenario.

\begin{tabular}{|l|c|c|c|c|c|c|c|c|c|c|c|}
\hline Scenario & C-RUSLE & LLE & Stream & \multicolumn{3}{|c|}{ HC - all study area } & \multicolumn{5}{|c|}{ HC - burned área } \\
\hline name & mean & TL (m) & TL (m) & mean & sd & $\delta^{*}$ & $\delta^{* *}$ & mean & sd & $\delta^{*}$ & $\delta^{* *}$ \\
\hline PreF & 0.1499 & 31024 & 16058 & -3.488 & 1.188 & --- & --- & -4.046 & 1.170 & --- & -- \\
\hline PostF-1 & 0.1890 & 31024 & 16058 & -3.212 & 1.072 & 7.9 & 7.9 & -3.534 & 1.104 & 12.7 & 12.7 \\
\hline PostF-2 & 0.2146 & 36612 & 15844 & -3.027 & 1.026 & 13.2 & 5.7 & -3.212 & 1.049 & 20.6 & 9.1 \\
\hline PostF-3 & 0.2146 & 36612 & 47135 & -2.869 & 1.067 & 17.7 & 5.2 & -2.980 & 1.062 & 26.3 & 7.2 \\
\hline PostF-4 & 0.2030 & 36612 & 47135 & -2.926 & 1.066 & 16.1 & -2.0 & -3.068 & 1.060 & 24.2 & -2.9 \\
\hline PostF-5 & 0.1974 & 36612 & 47323 & -2.956 & 1.066 & 15.3 & -1.0 & -3.114 & 1.059 & 23.0 & -1.5 \\
\hline Fut-1 & 0.1861 & 36612 & 47349 & -3.023 & 1.068 & 13.3 & -2.3 & -3.218 & 1.057 & 20.5 & -3.3 \\
\hline Fut-2 & 0.1380 & 36612 & 47349 & -3.536 & 1.179 & -1.4 & -17.0 & -3.994 & 1.078 & 1.3 & -24.1 \\
\hline
\end{tabular}



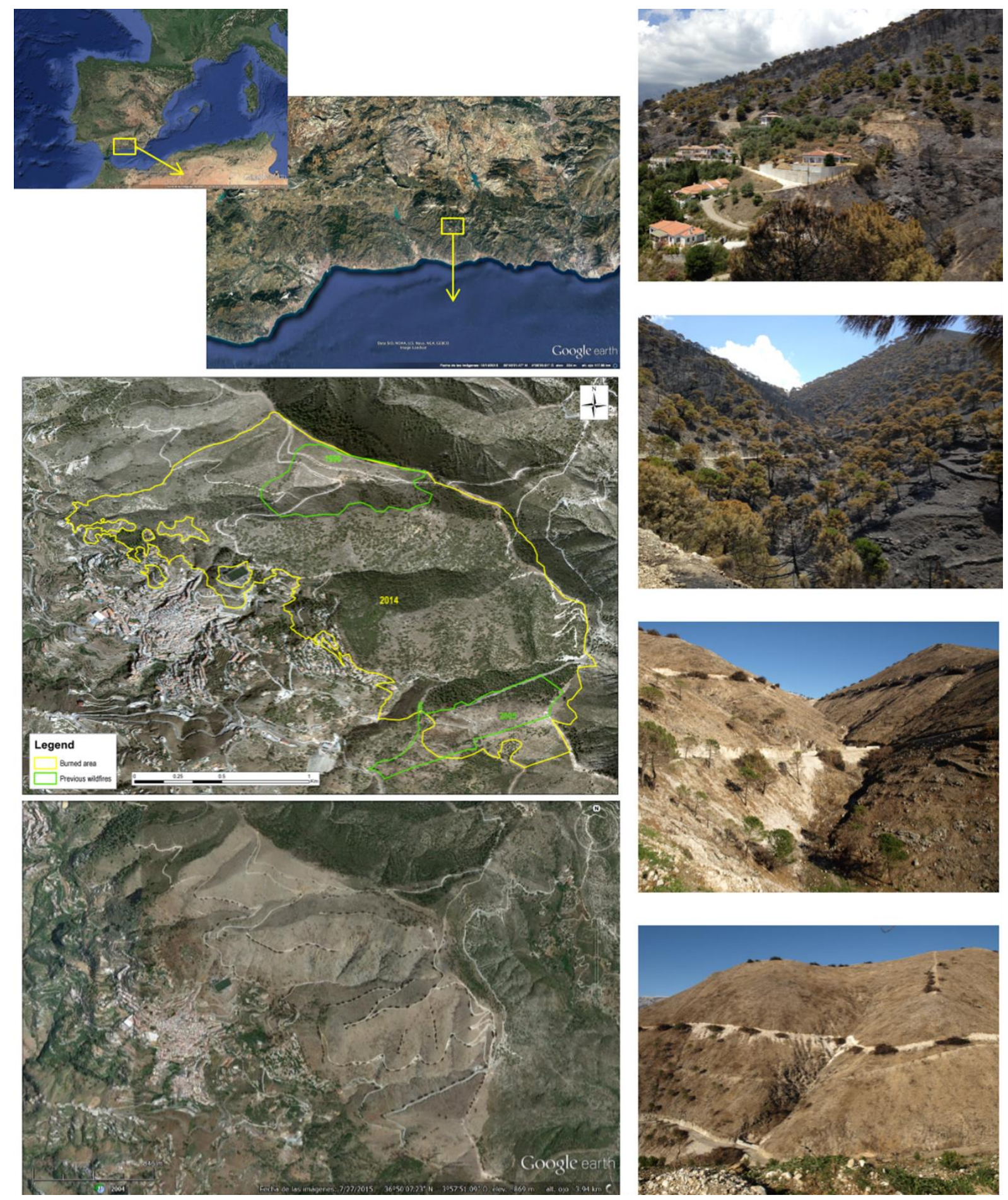

587 Figure 1. Location of the study site (top, left) and pre- (middle, left) and post-fire view

588 (bottom, left). General views of the burned area (right, from top to bottom): wildland urban

589 interphase area affected by the wildfire, burned trees partially affected by the fire, hillslopes

590 after removing vegetation, and hillslopes with accumulated burned and cut trees and a new

591 skid trail. 


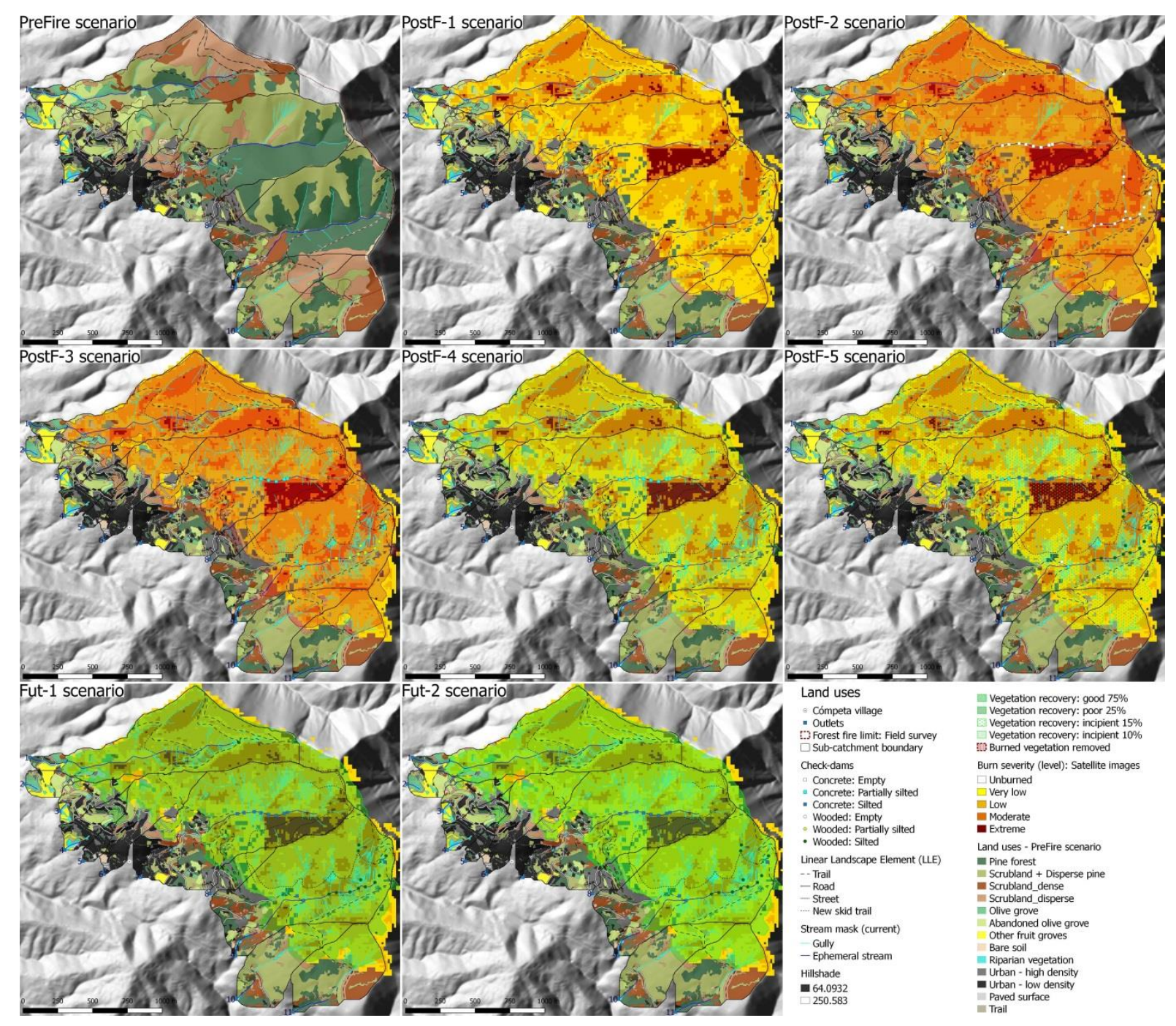

Figure 2. Maps of land uses of the eight simulated scenarios before and after the wildfire. 
Burned area \& Burn severity

- Cómpeta village

- Outlets

[-3 Forest fire limit: Field survey

$\square$ Sub-catchment boundary

Post-fire rill \& Gully network

- Gully

- Ephemeral stream

Burn severity (level): Satellite images

$\square$ Unburned $(<100)$

$\square$ Very low $(100-270)$

$\square$ Low $(270$ - 440)

Moderate $(440-660)$

- Extreme (>660)

Hillshade

- 64.0932

250.583

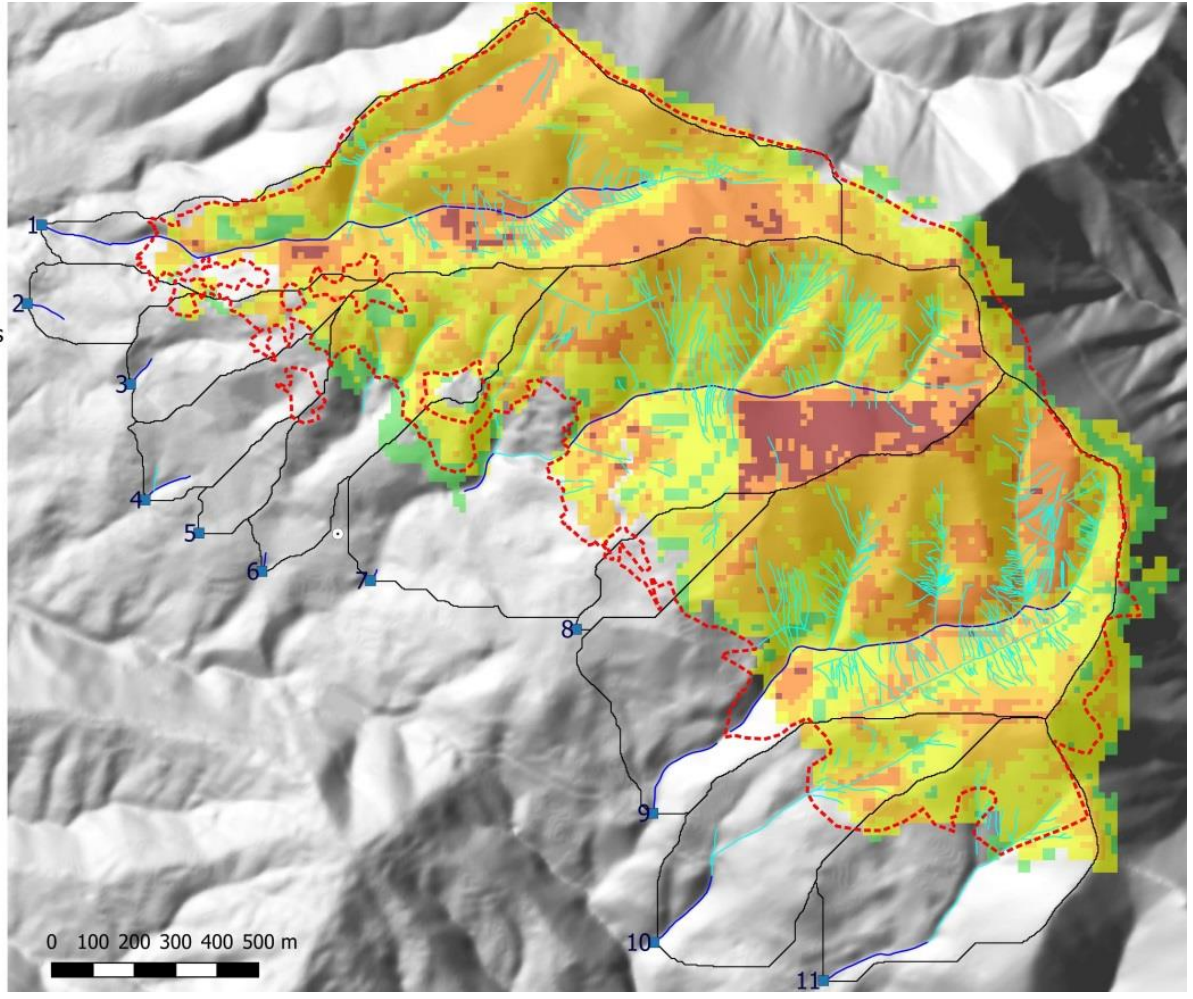

Figure 3. Map of burn severity obtained with the dNBR index and postfire network of rills and gullies. 


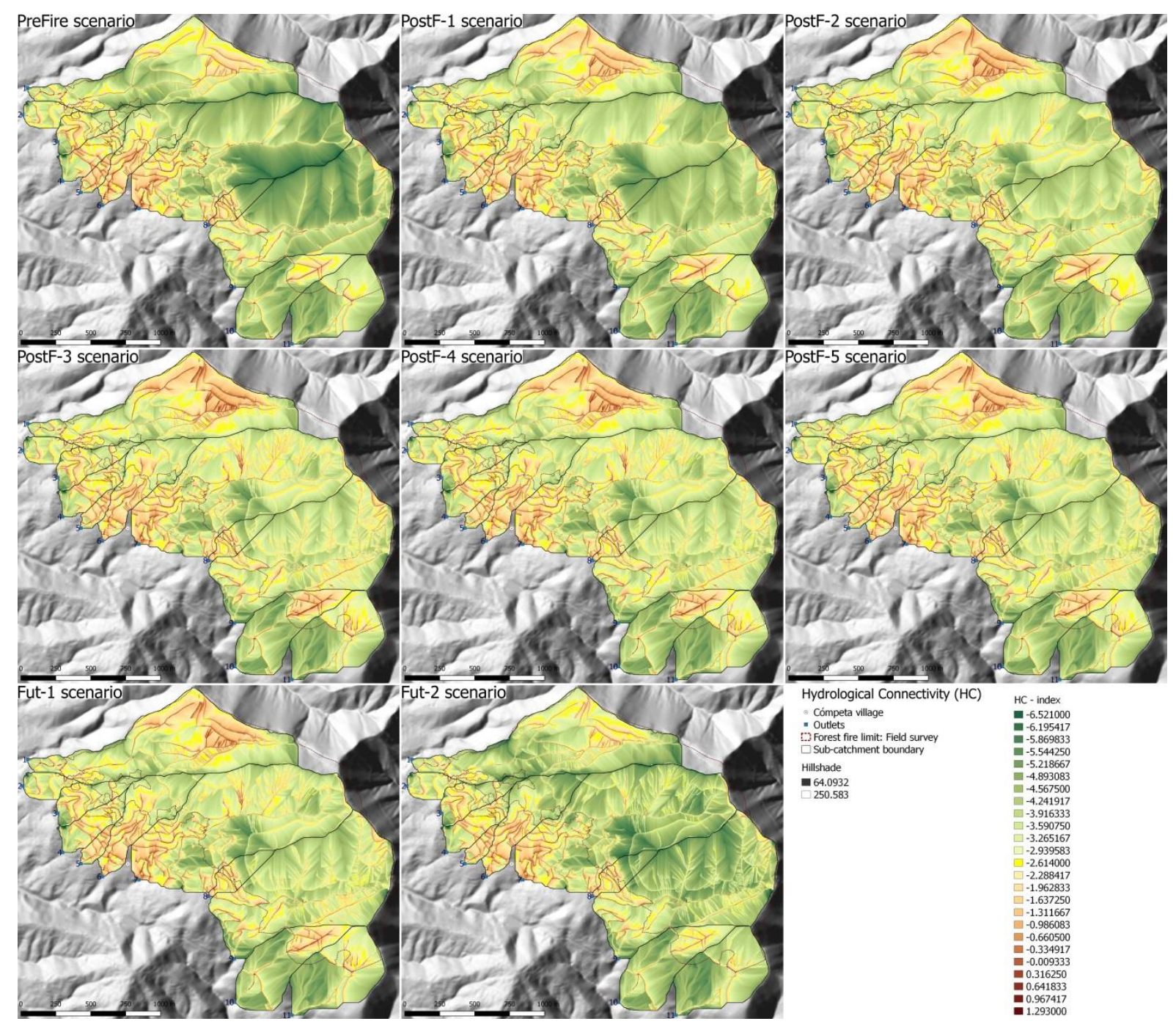

\section{2}

Figure 4. Maps of simulated hydrological connectivity in the pre-fire and seven post-fire scenarios.
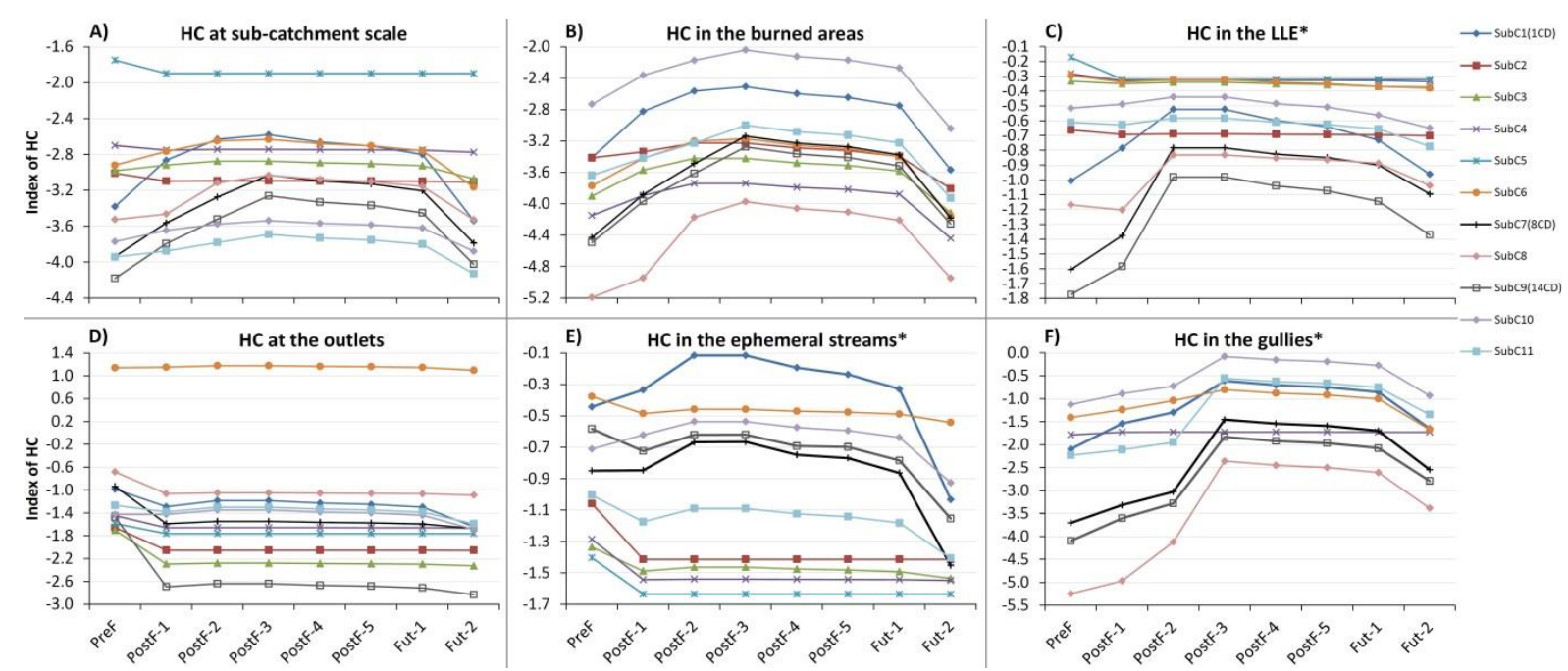

Figure 5. Mean values of hydrological connectivity (HC) at the outlets, ephemeral streams, gullies, linear landscape elements (LLE), burned and total sub-catchment area, in the eleven SubC and during the eight simulated scenarios. *: Considering the maximum extension of the feature. 

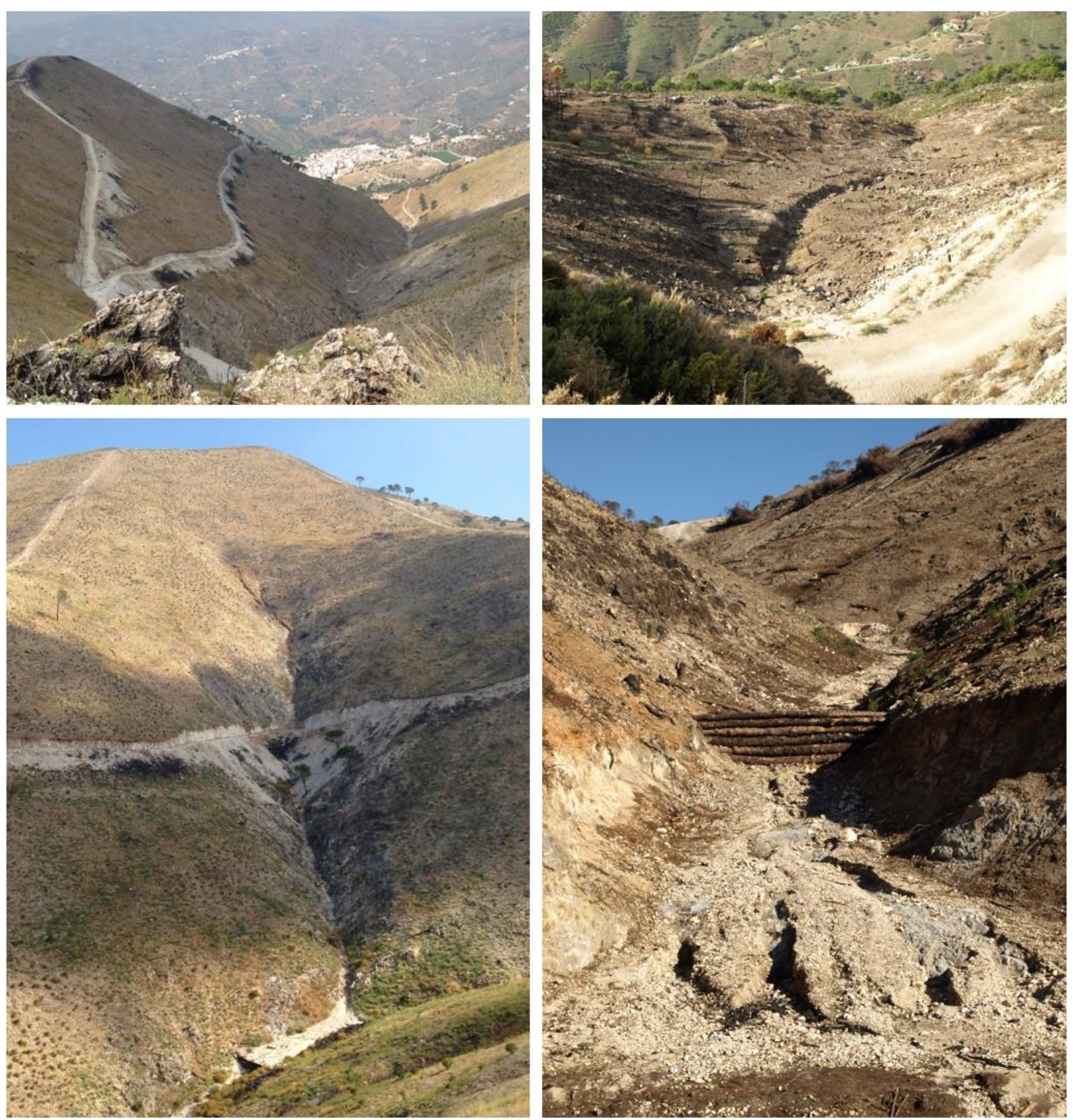

Figure 6. Top left: view of SubC-7 with a new skid trail, accumulated cut burned trees and partially silted check-

613 dams along the channel; top right: new gully formed after wildfire (width: $2.45 \mathrm{~m}$ ) in the outlet of SubC-10;

614 bottom left: headwater located in SubC-9 with rills in hillslopes and fully silted wooden check-dam at the

615 bottom; bottom right: fully silted wooden check-dam and new deposits of sediments with incisions ahead

616 located near the outlet of SubC-9. 